\title{
Nová směrnice EU o pitné vodě
}

\section{DANA BAUDIŠOVÁ, FRANTIŠEK KOŽí̌EK}

Klíčová slova: pitná voda - směrnice EU - mikrobiologické ukazatele - mikrobiologické indikátory

\section{SOUHRN}

V únoru 2020 byl schválen návrh kompletní novely směrnice 98/83/ES o jakosti vody určené pro lidskou spotřebu. Nová směrnice vyšla po všech úředních procedurách dne 16. prosince 2020. Vzhledem k tomu, že změny ve výše uvedené směrnici jsou rozsáhlé, a vzhledem k zaměření tohoto mimořádného čísla VTEI jsou v tomto príspěvku prezentovány pouze ty části směrnice, které se bezprostředně týkají mikrobiologických ukazatelů (Escherichia coli, intestinální enterokoky, Clostridium perfringens, koliformní bakterie, počty kolonií, bakterie rodu Legionella a somatické kolifágy), se zaměřením na príslušné novinky.

\section{ÚVOD}

Evropské směrnici, která upravuje minimální požadavky na kvalitu a kontrolu pitné vody (směrnice Rady 98/83/ES o jakosti vody určené pro lidskou spotřebu), bylo v roce 2020 již 22 let. I když má v sobě zabudováno ustanovení, že Evropská komise má každých 5 let přezkoumat její aktuálnost a v případě potřeby zajistit její novelizaci, trvalo velmi dlouho, než se k potřebné zásadní novele přistoupilo. Již v roce 2003 proběhl dvoudenní seminář v Bruselu, jehož výstupem bylo doporučení na poměrně významné změny (tehdy se právě objevil nový "hit" v podobě posouzení rizik čili water safety plans). Nicméně tehdy se k novele nepřistoupilo s odůvodněním, že členské země mají dosud málo zkušeností s fungováním směrnice v praxi a že je potřeba vyčkat dalších pět let. Ke stále potřebnější novele se však nepřistoupilo ani za dalších pět či deset let, byt to bylo ze strany Evropské komise (EK) opakovaně slibováno. Tehdy již byly na vině „vyšší politické hry", resp. určité napětí mezi EK, Radou a Evropským parlamentem.

Když už byla situace neudržitelná, provedla EK v roce 2015 aspoň novelu př́loh II a III (směrnicí Komise (EU) 2015/1787), která však byla zcela nedostatečná vzhledem k moderním potřebám. Až 1. 2. 2018 byl zveřejněn dlouho očekávaný návrh EK, týkající se kompletní novely směrnice. Poté byl tento návrh přibližně rok projednáván jednak v Radě EU, která přijala své oficiální stanovisko 5. 3. 2019, jednak v Evropském parlamentu (EP), který naštěstí - i přes nové volby v květnu 2019 - stačil schválit svou pozici do poloviny roku 2019. Na podzim 2019 byly zahájeny pod finským předsednictvím trialogy (Rada - EK - EP), které se podařilo zdárně dokončit těsně před koncem roku, takže v únoru 2020 byl zveřejněn kompletní návrh novely této směrnice. Nová směrnice o jakosti vody určené pro lidskou spotřebu byla po všech úředních procedurách ze strany právni a jazykové služby vydána dne 16. prosince 2020 (č. 2020/2184). Transpozice do legislativy České republiky by měla proběhnout do dvou let. Změny se dotknou nejen zákona o ochraně veřejného zdraví (č. 258/2000 Sb.) a jeho prováděcích vyhlášek (č. 252/2004 Sb. a č. 409/2005 Sb.), ale velmi pravděpodobně i zákona o vodách (č. 254/2001 Sb.) a zákona o vodovodech a kanalizacích pro veřejnou potřebu (č. 274/2001 Sb.) a jejich prováděcích vyhlášek.
V nové směrnici [1], je hodně významných novinek, které se dotknou nejen provozovatelů vodovodů, pracovníků orgánů ochrany veřejného zdraví (KHS) či pracovníků analytických laboratoří. Jedná se např. o povinné zavedení př́stupu založeném na posouzení a řízení rizik systémů zásobování pitnou vodou (včetně oblastí povodí, která souvisí s místem odběru jímání vody určené k lidské spotřebě) a posouzení rizik domovního rozvodného systému; dále bude na úrovni EU sjednocen systém testování materiálu pro styk s pitnou vodou a jeho zezávaznění.

Vzhledem $k$ tomu, že změny $v$ této novele jsou rozsáhlé a toto mimořádné číslo VTEI je speciálně zaměřeno, budou v tomto príspěvku prezentovány především body, které se bezprostředně týkají stanovení a hodnocení mikrobiologických ukazatelů.

\section{MINIMÁLNÍ POŽADAVKY NA HODNOTY UKAZATELŮ, POUŽÍVANÉ K POSOUZENÍ JAKOSTI VODY URČENÉ K LIDSKÉ SPOTŘEBĚ}

E. coli a intestinální enterokoky se považují za "klíčové ukazatele" a četnost jejich monitorování nepodléhá možnosti snížení, a to ani na základě výsledků posouzení rizik systémů zásobování vodou. Jejich limitní hodnota je 0 KTJ ve $100 \mathrm{ml}$, která bude v české legislativě zavedena jako NMH (nejvyšší mezní hodnota), pro vodou stáčenou do lahví nebo nádob je limit 0 KTJ/250 ml. Pro stanovení E. coli jsou ve směrnici predepsané metody podle ČSN EN ISO 9308-1 [2] a ČSN EN ISO 9308-2 [3]; pro stanovení intestinálních enterokoků je předepsaná metoda podle ČSN EN ISO 7899-2 [4]. Všechny tyto metody jsou v českých mikrobiologických laboratořích běžně používané.

\section{INDIKÁTOROVÉ UKAZATELE}

Indikátorové ukazatele nemají prímý vliv na veřejné zdraví. Jsou však důležitým nástrojem ke zjištění, jak fungují zařizení pro výrobu a distribuci pitné vody, a jsou též důležitým prostředkem pro hodnocení jakosti vody. Mohou pomoci odhalit nedostatky při úpravě či distribuci vody a hrají důležitou úlohu z hlediska zvyšování a zachování důvěry spotřebitelů v její jakost. Z mikrobiologických ukazatelů jsou indikátorové ukazatele koliformní bakterie, počty kolonií při $22^{\circ} \mathrm{C}$ a Clostridium perfringens.

Pro stanovení koliformních bakterií jsou předepsány metody podle ČSN EN ISO 9308-1 [2] a ČSN EN ISO 9308-2 [3], tedy shodné jako pro stanovení E. coli. Předepsaná hodnota $0 \mathrm{KTJ} / 100 \mathrm{ml}$ (pro vodu stáčenou do lahví nebo nádob 0 KTJ/250 ml) bude zřejmě zavedena jako mezní hodnota. 
Pro stanovení počtu kolonií při $22{ }^{\circ} \mathrm{C}$ je předepsaná již zavedená a běžně používaná metoda podle ČSN EN ISO 6222 [5]. Jejich „předepsaná limitní hodnota“ v 1 ml je stanovena jako „bez abnormálních změn”. I tento princip hodnocení se již v České republice řadu let používá. Ve směrnici nejsou uvedeny počty kolonií při $36^{\circ} \mathrm{C}$, to však není změna, nevyskytovaly se pro nebalenou pitnou vodu ani v původní směrnici. Přesto se očekává, že tento ukazatel se bude u nás používat i nadále.

C. perfringens se bude stanovat metodou podle ČSN EN ISO 14189 [6]. Tuto metodu (kultivace C. perfringens na TSC agaru a konfirmace kyselou fosfatázou) již mají mnohé laboratoře zavedenou a výsledky zkoušek způsobilosti ukazují, že úspěšně. Dnes jsou již k dispozici vhodná (pracovně i finančně) činidla, která nejenže dobře konfirmují přeočkované kolonie, ale Ize je použít i přímo na kolonie vyrostlé na membránových filtrech (obr. 1). Pro C. perfringens je ve směrnici uvedena hodnota 0 KTJ/100 ml s tím, že se má stanovovat „včetně spor". Tento termín je však zavádějící, spory se totiž stanovují vždy. Znamená to, že se budou stanovovat jak spory, tak vegetativní buňky, tudíž se nebude provádět eliminační krok (tepelná inaktivace buněk). C. perfringens se má stanovovat v případě, že to vyplyne z posouzení rizik.

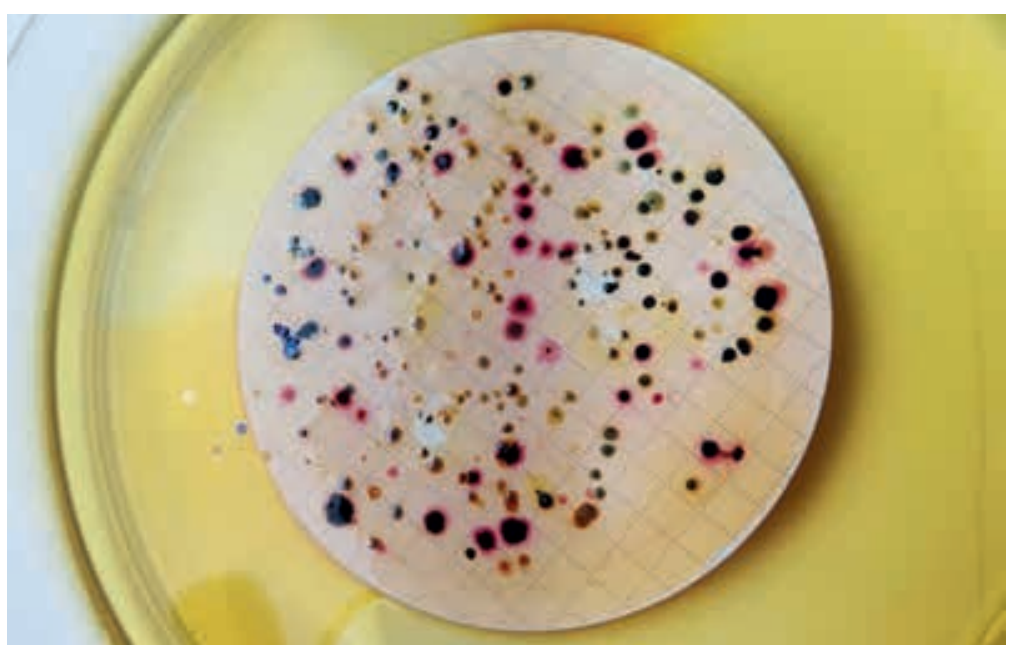

Obr. 1. Tmavé kolonie vyrostlé na TSC agaru v anaerobních podmínkách, které po působení činidla na kyselou fosfatázu zčervenaly, jsou považovány za C. perfringens Fig. 1. Dark colonies, growing on TSC medium in anaerobic condition, that turn red as effect of acide phosphatase reagent are supposed to be Clostridium perfringens

\section{UKAZATELE RELEVANTNÍ PRO POSOUZENÍ RIZIK DOMOVNÍHO ROZVODNÉHO SYSTÉMU}

Ještě před zahájením novely si EK nechala zpracovat od Světové zdravotnické organizace (WHO) studii, které ukazatele by se mohly ze směrnice vypustit a které naopak by se měly nově zařadit, resp. u kterých ukazatelů by měla být upravena limitní hodnota. WHO ve své zprávě [7] uvedla, že v EU je ročně hlášeno okolo šesti tisíc prípadů legionelózy (s desetiprocentní smrtností), a i když je toto číslo zřejmě značně podhodnoceno, stále to staví legionely na první místo co do př́činy úmrtí na nemoci související s vodou. Bakterie rodu Legionella nebyly dosud ve směrnici uvedeny. Bylo to $v$ první řadě proto, že $v$ době, kdy se připravovala směrnice č. 98/83/ES - tedy v polovině 90 . let - bylo informací o výskytu legionel nepoměrně méně a situace se ani zdravotním úřadům, ani zákonodárcům nezdála tak naléhavá. Dalším důvodem může být skutečnost, že přestože se zmíněná směrnice nazývá „o jakosti vody určené pro lidskou spotřebu“ a podle definice se vztahuje také na vodu určenou pro kontakt s lidským tělem, řada členských zemí EU ji považovala za směrnici na pitnou, nikoliv teplou vodu. A právě domovní rozvody teplé vody jsou jedním z vhodných prostředí pro pomnožení legionel.
Jak již bylo uvedeno v úvodu, v novele směrnice je předepsáno posouzení rizik $v$ domovních rozvodech vody $v$ prioritních budovách, a právě legionely jsou jedním z hlavních ukazatelů. Prioritní budovy, na které se bude tato povinnost vztahovat, si určí na základě subsidiarity samy členské státy EU; může se jednat např. o zdravotnická zařízení, věznice, domovy pro seniory, vzdělávací zařízení, budovy s ubytovací kapacitou, sportovní a rekreační zařízení apod.

Pro bakterie rodu Legionella je stanovena hodnota 1000 KTJ/litr. Nápravná opatření lze zvažovat i v prípadě, že této hodnoty ukazatele není dosaženo, například v prípadě prokázaných infekcí a ohnisek nákaz. V takových př́padech by měl být zdroj infekce potvrzen a určen jeho biologický druh. Základní stanovení legionel se provádí metodou podle ČSN EN ISO 11731 [8]. Růst legionel z teplé užitkové vody je na obr. 2.

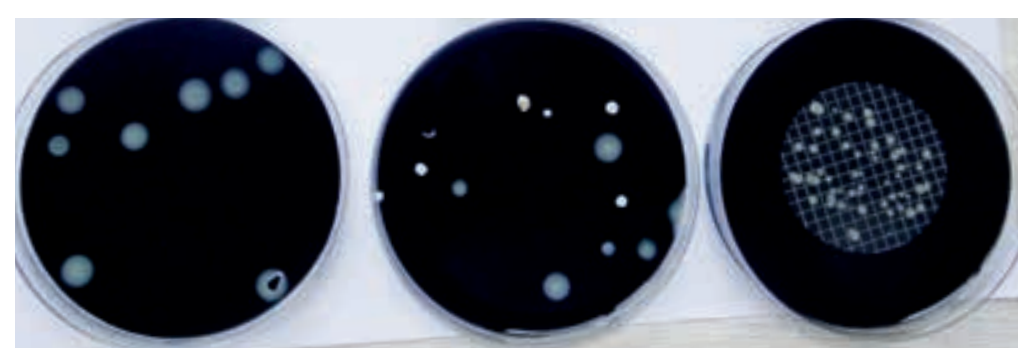

Obr. 2. Růst legionel z teplé užitkové vody (GVPC médium vlevo, BCYE médium uprostřed) a na membránovém filtru (GVPC médium, vpravo) Fig. 2. The growth of legionellae from warm water (GVPC medium on the left side, BCYE medium in the centre) and on the membrane filter (GVPC medium, on the right side)

\section{PROVOZNÍ MONITOROVACÍ PROGRAM}

Součástí provozního monitorovacího programu je také monitorování somatických kolifágů, aby se kontrolovala účinnost procesů úpravy, zaměřených na mikrobiologická rizika. Somatické kolifágy jsou bakteriální viry, napadající citlivé buňky E. coli. Stanovují se plakovou titrací, metodami podle ČSN EN ISO 10705-2 [9] a ČSN ISO 10705-3 [10]. Tento ukazatel se má sledovat, pokud to vyplyne z posouzení rizik. Je-li zjištěna př́tomnost somatických kolifágů $\checkmark$ surové vodě v koncentraci větší než 50 PTJ/100 ml, mělo by se toto stanovení provést po dokončení série kroků úpravy vody, aby bylo možno určit log hodnotu odstranění prostřednictvím existujících bariér a posoudit, zda je riziko průniku patogenních virů skrze úpravu dostatečně pod kontrolou.

S tímto ukazatelem jsou v České republice pouze minimální zkušenosti a $\vee$ následujících letech této problematice bude muset být věnována značná pozornost. A to nejen z hlediska laboratorního stanovení, ale i použití, príistupu a hodnocení tohoto ukazatele $v$ praxi.

Výsledky z analýz povrchové/odpadní vody [11-13] ukázaly, že somatické kolifágy vykazují určitou korelaci s E. coli, což ale může být u surové vody samozřejmě jinak. Pro začátek jsme ze studia výsledků E. coliz databáze „surová voda“ (ČHMÚ) vytipovali naše nejohroženější zdroje. Maximální hodnoty E. coli vyšší než 50 KTJ/100 ml vykazovalo 15 (27\%) povrchových a 5 (0,5\%) podzemních zdrojů v České republice. Nejohroženější se zdají být surové vody z podhorských povrchových toků, a to především v brzkém jarním období (zřejmě v souvislosti se zvýšenými průtoky v období tání sněhu).

Na obr. 3 jsou orientační výsledky (E. coli a somatické kolifágy) z pěti toků, které se $v$ blízkosti našeho odběrového místa alespoň částečně používají jako surová voda. V době odběru nebyly $v$ žádné z lokalit zaznamenány zvýšené průtoky. Somatické kolifágy byly stanoveny pomocí hostitelského kmene ATCC 13706, upravenou metodou od autorek Šimková a Miklošovičová [14], E. coli byla stanovena metodou podle ČSN EN ISO 9308-2 [3]. 


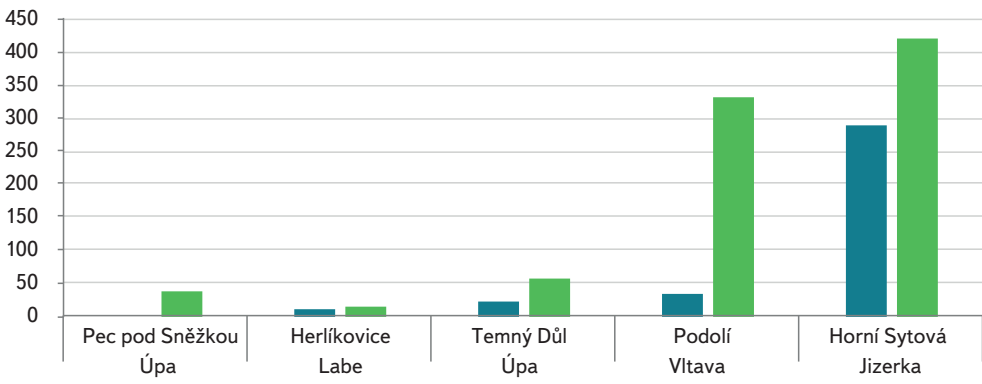

\section{Fágy PTJ $/ 100 \mathrm{ml}$ E. coli MPN $/ 100 \mathrm{ml}$}

Obr. 3. Výsledky stanovení E. colia somatických kolifágů ve vybraných povrchových tocích

Fig. 3. Results of E. coli and somatic coliphages detection in chosen surface waters

\section{Poděkování}

Vznik príspěvku byl podpořen v rámci MZ ČR - RVO (Státní zdravotní ústav - SZÚ, IČ 75010330).

\section{Literatura}

[1] Rada EU: Rada EU: Směrnice Evropského parlamentu a Rady (EU) 2020/2184 o jakosti vody určené k lidské spotřebě (přepracované znění). Pracovní verze č. j. st 6230 - 2017/0332 (COD) ze dne 6. 10. 2020. [2] ČSN EN ISO 9308-1 (75 7836): Kvalita vod - Stanovení Escherichia coli a koliformních bakterií - Část 1: Metoda membránových filtrů pro vody s nízkým obsahem doprovodné mikroflóry.

[3] ČSN EN ISO 9308-2 (75 7836): Kvalita vod - Stanovení Escherichia colia koliformních bakterií - Část 2: Metoda nejpravděpodobnějšího počtu.

[4] ČSN EN ISO 7899-2 (75 7831): Jakost vod - Stanovení intestinálních enterokoků - Část 2: Metoda membránových filtrů.

[5] ČSN EN ISO 6222 (75 7821): Jakost vod - Stanovení kultivovatelných mikroorganismů - Stanovení počtu kolonií očkováním do živného agarového kultivačního média.

[6] ČSN EN ISO 14189 (757865): Kvalita vod - Stanovení Clostridium perfringens - Metoda membránových filtrů.

[7] WHO: Drinking Water Parameter Cooperation Project. Support to the revision of Annex I Council Directive 98/83/EC on the Quality of Water Intended for Human Consumption (Drinking Water Directive). Recommendations. WHO Euro, Bonn 2017, 240 p.

[8] ČSN EN ISO 11731 (75 7881): Kvalita vod - Stanovení bakterí rodu Legionella.

[9] ČSN EN ISO 10705-2 (75 7871): Průkaz přítomnosti a kvantitativní stanovení bakteriofágů - Část 2: Kvantitativní stanovení somatických kolifágů.

[10] ČSN ISO 10705-3 (757871): Kvalita vod - průkaz přítomnosti a kvantitativní stanovení bakteriofágů Část 3: Validace metod pro zkoncentrování bakteriofágů z vody.

[11] BAUDIŠOVÁ, D. a FUKSA, J. Jakost vody v Labi a dolní Vltavě - mikrobiologické ukazatele. Bulletin Projektu Labe 13/1997.

[12] BAUDIŠOVÁ, D. Mikrobiální zatížení Labe. VTEl, 11-12/1998, s. 409-416, 1998

[13] ČAPKOVÁ J a BAUDIŠOVÁ D ZKOušení domovních čistíren odpadních vod podle ČSN EN 12566-3 ve VÚV TGM. v. v. i. In: Andrea Benáková, Iveta Růžičková Sborník přednášek a posterových sdělení z 12. bienální konference a výstavy VODA 2017. Poděbrady, 20. 9. 2017. Brno: Tribun EU, s. r. O., s. 219-222. 20017.

[14] ŠIMKOVÁ, A. a MIKLOŠOVIČOVÁ, A. Metodika na kontrolu kontaminácie vôd enterovírusmi. Acta hygienica epidemiologica et microbiologica, príloha č. 20/81986, s. 1-19.

\section{Autoři}

RNDr. Dana Baudišová, Ph.D.

凶dana.baudisova@szu.cz

ORCID: 0000-0003-3993-6845

MUDr. František Kožíšek, CSc.

凶frantisek.kozisek@szu.cz

ORCID: 0000-0002-0107-6969

Státní zdravotní ústav

Přispěvek prošel lektorským rízením.

DOI: 10.46555/VTEI.2020.11.00

\section{NEW EUROPEAN UNION DIRECTIVE ON DRINKING WATER}

\section{BAUDISOVA, D.; KOZISEK, F.}

National Institute of Public Health

Keywords: drinking water - EU directive microbiological parameters - microbiological indicators

A proposal for a complete amendment to Directive 98/83/EC on the quality of water intended for human consumption was approved in February 2020. The new Directive came into force after all official procedures on 16 December 2020. Since the changes in the above-mentioned Directive are large and given to the focus of this extraordinary VTEI issue, only parts of the Directive directly related to microbiological indicators (Escherichia coli, intestinal enterococci Clostridium perfringens, total coliforms, colony counts, Legionella spp. and somatic coliphages) are presented in this paper, focusing on relevant news. 